\title{
Applying an organisational agility maturity model
}

\author{
David Gunsberg, Bruce Callow, Brett Ryan, Jolyon Suthers and \\ Penny Anne Baker \\ Department of Digital Solutions, Griffith University, Brisbane, Australia, and \\ Joanna Richardson \\ Department of Library and Learning Services, \\ Griffith University, Meadowbrook, Australia
}

Received 23 October 2017 Revised 6 February 2018 Accepted 27 May 2018

\begin{abstract}
Purpose - The purpose of this paper is to identify the baseline model required to measure whole-oforganisation agility within a university information services division. The paper seeks to analyse the process of identifying and applying such a model.

Design/methodology/approach - The qualitative methodology applied is that of a single case study. The organisation analysed was an Australian university's information services division. A structured survey, based on Wendler (2014), was administered to all staff as part of a multi-phased approach, thus facilitating a triangulation process.

Findings - The current research has confirmed the applicability of Wendler's model to the higher education information technology sector. Application of the model establishes not only a baseline agility maturity score across the whole-of-organisation but also provides granular scores based on organisational units. Triangulation of survey results is recommended to achieve a more in-depth perspective.

Research limitations/implications - Further research comparing similarly and differently sized universities could provide valuable insights. More research is needed to extend the applicability of Wendler's model to a wider range of domains and industries.

Practical implications - The grouping of survey questions under particular broad themes reflected the strategic focus of the division being surveyed. Organisations implementing the proposed model will need to select themes that correspond with their respective strategic goals and culture.

Originality/value - The paper has extended the research and resultant model developed by Wendler by applying them not only to both managers and staff but also to a different domain, specifically higher education.

Keywords Self-assessment, Agility framework, Enterprise agility, Information technology services

Paper type Case study
\end{abstract}

\section{Introduction}

Higher education is facing significant disruption through technology that is fundamentally changing how universities operate (Aronowitz et al., 2015; Adams Becker et al., 2017). The impact of these changes on both culture and operations is necessarily transformative, and will require an understanding of core capabilities to ensure the required leadership. Universities must be agile if they are to respond quickly to the changing legislative and competitive environment and the changes in teaching, learning and research practice. Consequently their information services must ensure that they have the capability to be agile in response to these new challenges.

Agility is required at all levels of information service divisions as a way of operating, not just at the leadership/managerial level. The response needed to achieve this may lead to "a sweeping rethink of organizational structures, influence, and control", which inherently threatens organisational health (De Smet et al., 2016, p. 1). However, as Aronowitz et al. (2015, p. 5) observed, managers may not spend sufficient time assessing the current state of their organisation because they assume that they have a good understanding of that current state. In short, they do not take time to survey the scene and establish a benchmark.

Based on the background above, the authors were interested to determine how a university information services division could rate its progress towards achieving organisational agility and

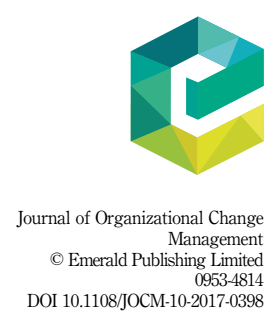


also identify areas on which it should focus its efforts to improve its agility. The purpose, therefore, of this study is to identify the most appropriate organisational agility maturity model that could be applied to an information technology service division within a university.

This study contributes to the organisational literature by responding to the call for more research on whole-of-organisation agility maturity models (Sherehiy et al., 2007; Wendler, 2012; Wendler and Stahlke, 2014) and their specific application across a range of domains other than just the commercial software and IT service industry (Wendler and Stahlke, 2014).

The paper is structured as follows. Following on from this introductory section, Section 2 presents a literature review of frameworks, or similar concepts, that describe the key components of organisational agility. Section 3 presents the methodology used. Section 4 describes the results obtained. Section 5 examines the authors' findings in terms of the research questions, and discusses implications and limitations. Finally, Section 6 offers a brief conclusion, including suggested further research.

\section{Literature review}

While the concept of agility is not new, it arguably came into prominence, particularly in regard to software development and project management, through the promulgation of the so-called "Agile Manifesto" (Beck et al., 2001). The development and uptake of various agile methodologies has subsequently been well chronicled in the literature (Ionel, 2009; Dingsøyr et al., 2012; Maurer and Hellmann, 2013; Al-Saleem and Ullah, 2015).

Agile methodologies, as such, have been transforming the way in which organisations undertake software development and project management for the past several decades (Rigby et al., 2016). A more recent and broader concept is that of applying agile practices to whole-of-organisation. In fact, Gartner (2006, p. 1) defined agility as "the ability of an organization to sense or create environmental change and respond efficiently and effectively to that change", with the emphasis being on the organisation rather than its discrete elements.

As Sahota (2013, p. 1) suggested, the latter involves agile-as-a-mindset: "Adopting Agile practices focuses on modest process improvements that do not disrupt the organizational system. At the other extreme, transformation fundamentally alters the nature of the company - a paradigm shift". Based on the results of a 2014 worldwide survey, Manpower (2014) reported that in Australasia 78 per cent of respondents ranked as "important" the role of organisational agility in achieving company business goals. However, only 4 per cent agreed to some extent that their organisation had actually demonstrated a commitment to pursuing more organisational agility over the previous 12 months. It is uncertain whether part of the reason for lack of action could be attributed to a lack of clarity regarding how to achieve this.

Managing the transition from a current state to that of being an agile organisation connotes an underlying assumption that there is consensus as to what constitutes such an entity. However, there is a general lack of clearly defined frameworks for explaining agility from an organisational perspective (Sherehiy et al., 2007; Wendler and Stahlke, 2014). The broad application of agility at the enterprise level has proved to be challenging. The lack of an agreed approach, which actually covers the whole-of-organisation, lies at the core of the problem. According to Sherehiy et al. (2007, p. 459):

There is no commonly accepted definition of EA [enterprise agility], and there are a large number of opinions concerning the meaning of this term. Furthermore, there is a problem to differentiate the agility concept from adaptability and flexibility. Currently, all three terms: "adaptability", "flexibility", and "agility" are used in the research on how organization can cope with unpredicted and dynamically changing environment.

For his part, DeSouza (2006, p. xiii) has suggested four key attributes:

How do we know an organization is agile? Being agile will result in the ability to (1) sense signals in the environment, (2) process them adequately, (3) mobilize resources and processes to take 
advantage of future opportunities, and (4) continuously learn and improve the operations of the organization. Furthermore, the preceding activities need to occur in quick time cycles and with minimal cost and effort.

While proposing a high-level overview of agility in relation to the whole organisation,

DeSouza did not offer any more details, by which one could then construct a maturity model.

Kassim and Zain (2004) have highlighted the importance of information systems which supply accurate, timely and easily available information so that organisations can quickly adapt to changes. According to Tsourveloudis and Valavanis (2002), who proposed a framework to measure and assess manufacturing agility, organisational agility is comprised of many different individual and grouped infrastructure parameters. For her part, Charbonnier-Voirin (2011) created "measurement scale likely to represent the practices which contribute to developing the agile firm's capabilities of reactivity, reading the market, and organizational learning" (p. 145).

Bottani $(2009,2010)$ investigated different assessment methods of organisational agility and analysed manufacturing companies in Europe. From her findings, she identified several clusters of organisations that represent different agility levels. In addition, she performed a principal component analysis to describe the clusters with a small number of characteristics. However, her focus is on manufacturing, rather than software and IT service industry, which is the domain on which the current case study is based. According to Lu and Ramamurthy (2011), IT spending does not automatically lead to greater agility. Therefore, they advise, managers need to examine how other elements, such as culture, structure, process and people, interact with technology to enable organisational agility.

Harraf and Tate (2014) described ten agility attributes that are common to successful organisations. Rothschild (2015) has outlined eight "building blocks" of organisational agility. Gartner (Norton et al., 2014) has defined best practice principles for organisations wishing to move from a project-level agile development focus to end-to-end enterprise agile delivery.

Aghina et al. (2015, p. 2) asserted that "the ability to be both stable and dynamic [is] the essence of true organizational agility". They have identified three core organisational areas where balancing the inherent tension between stability and flexibility is important: organisational structure, governance and processes. While the authors did not reference any model as such, they did include a checklist to test an organisation's current agility level. Respondents pick the words that best describe how it feels to work at a given company. The results indicate whether a company's "dynamic capability" tends to be more "start-up" or "agile", and whether its "stable backbone" tends to be more "trapped" or "bureaucratic". No explanation is provided as to how to interpret the scores.

In terms of creating a conceptual framework for defining the key components of organisational agility, Holbeche (2015, p. 55) has structured her approach based on strategic agility: "The ability to continuously adjust and adapt strategic direction in core activities, as a function of strategic ambitions and changing circumstances and create not just new products and services but also new business models and innovative ways to create value in complex and fast-changing conditions". Underlining the importance of resilience as a co-factor, she has outlined the key characteristics when shifting from conventional strategy thinking to agility strategising. In addition, she has created a visual representation of the key components which define an organisation's agility and resilience, based on four highlevel concepts: agile strategising, agile operations, agile people practices and agile linkages. The "components", e.g. continuous learning, deep customer insight and values-based leadership and management, could be used to develop a self-assessment questionnaire.

A useful model has been developed by Allied Consultants Europe (ACE). Allied Consultants Europe (2010, p. 5) defined six “dimensions" for determining the agility level of organisations: leadership and management, innovation, structure, strategy, learning and change, and culture. For each dimension, there are two or more actions against which an 
organisation can rate itself, e.g. fostering a learning organisation as a crucial part of strategy. The approach is designed to be very high level.

For his part, having acknowledged the highly competitive environment specifically within the commercial software and IT service industry, Wendler (2014) noted the relative scarcity of available tools and methods to help these organisations assess and improve their organisational agility. Wendler's (2014) research focussed on developing a maturity model to address this gap, based on the following rationale:

The identified requirements of a comprehensive representation of the whole organization, an intuitive tool that is easy to use, a determination of the current state of organizational agility, and directions for further improvement can be fulfilled with a maturity model. A maturity model describes and determines the state of perfection or completeness (i.e. the maturity) of certain objects. The progress in maturity can be observed and managed by the definition of maturity stages or levels that measure the completeness of the analysed objects via different sets of (multidimensional) criteria (p. 1198).

Wendler (2013) had already undertaken an extensive review of the literature and ultimately identified and compared 28 frameworks or similar concepts, which could be considered as possible candidates. He subdivided them into three categories of approaches to assessment: the first group used various metrics; the second group used methods such as the analytic hierarchy process; and the third group was based on fuzzy logic.

Wendler (2014) concluded that:

The available approaches suffer from some limitations regarding their applicability to determine the level of organizational agility in practice. This weakness stems either from a too specialized orientation and, hence, an insufficient reflection of the whole organization with its interaction of people, structures, process, and technologies, as outlined above, or from the utilization of relatively complex algorithms, limiting an intuitive and ad hoc usage by management. In addition, although the available approaches are able to determine the current state of agility, they normally do not support management in suggesting further actions for improvement or development (p. 1198).

Wendler (2014) subsequently developed his own model ("Organizational Agility Maturity Model"), complete with a multi-part questionnaire for use by commercial software and IT service organisations. The objective of the model was to provide "a theoretically and empirically grounded structure of organizational agility supporting the efforts of developing a common understanding of the concept" (p. 1197), given the lack of consensus in the literature as to what constitutes an "agile organisation".

In their descriptive results of the application of the model to the software and IT service industry worldwide, Wendler and Stahlke (2014) identified the specific target group for their survey questionnaire as "general and IT-related decision-makers (like CEOs, CTOs, Managers, and employees in leading positions)" (p. 4). General staff ("employees") were not included. However, in their recommendations regarding further research, they identified two areas in particular: replicate the survey with different target groups, e.g. employees or roles; and apply the survey to other domains and industries.

Based on their recommendations, this paper aims to bridge this gap in the body of knowledge on this topic by examining the use of Wendler's survey with all staff, i.e. managers and general staff, in a non-commercial domain, specifically the higher education industry. The authors, therefore, propose the following research questions:

$R Q 1$. Is Wendler's organisational agility maturity model applicable to an information technology (IT) service division within a university?

$R Q 2$. Is such a model equally suitable for administering across staff at all levels of the organisation?

RQ3. Is any additional information required to fully assess the overall maturity of the agility of a university's IT service division? 


\section{Methodology}

3.1 The case study

Organisational agility

According to Yin (1984), social scientists in particular have used this methodology for many years to examine contemporary real-life situations and provide the basis for the application of ideas and extension of methods. It is well suited for exploring new processes or behaviours (Meyer, 2001) and for understanding complex issues (Zainal, 2007). As Gerring (2004, p. 342) observed, a case study should be "an intensive study of a single unit [...] a spatially bounded phenomenon - e.g. a nation-state, revolution, political party, election, or person - observed at a single point in time or over some delimited period of time".

In regard to case study design, it is better to use a single case study when the researcher wants to study, for example, a person or a group of people (Yin, 1984). Based on his own research, Wendler (2014, p. 1204) advocated the use of case studies to further validate his model. He suggested that future research should use the results of his study to "develop further confirmatory approaches" (Wendler, 2016, p. 462). The authors selected the Division of Information Services at Griffith University as an example of the application of his model in a different industry from the one he surveyed. This choice reinforces Gustafsson's (2017, p. 2) view that the "conclusion that is aimed by a case study can be either illustrative or confirmable". The authors' primary objective was to confirm the applicability of Wendler's model to a non-commercial IT software and service industry.

\subsection{The case subject}

Griffith University is a comprehensive, research-intensive university, ranking 32nd in the 2017/2018 QS University Rankings Top 50 Under 50 (Quacquarelli Symonds, 2017). Located in the rapidly growing corridor between Brisbane and the Gold Coast in Southeast Queensland, Australia, the University offers more than 200 degrees across five campuses to almost 50,000 students from 130 countries studying at undergraduate through to doctoral level in one of four broad academic groups: arts, education and law; business; science; and health.

The key features of the University's current structure were introduced in 1997, when the majority of support services were organised as centralised, multi-campus offices. As a result, the Division of Information Services (INS) became one of the most centralised and integrated information services models in Australian higher education, and remained that way until 2017. At the time the work described in this paper was undertaken, the Division had integrated eResearch, library and information and communication technology into a single organisation, comprised of eight portfolios. Of these, two had a predominantly library focus: library and learning services, and information management. eResearch Services provided access to specialist eResearch technologies, as well as library and information professionals. Four portfolios covered various aspects of enterprise information technology: IT architecture and solutions; enterprise information systems; information technology services; and information technology infrastructure. The eighth portfolio was responsible for planning and engagement.

While the only constant within both higher education and information technology may be change, another truism is that people remain an organisation's most valuable asset (Allen, 2014). That said, INS realised that change and contented employees do not always easily co-exist. Recognising the potential inherent tension, the Division embarked on a strategic plan to understand how its workforce was faring. Over a period of six months, beginning in the second half of 2016, INS launched three targeted surveys. The first gauged the level of employee engagement, the second measured the maturity of organisational agility and the third was a workplace culture assessment. It is important to note that none of these were staff satisfaction surveys.

The overall objective was to test the hypothesis that INS was typical of large organisations in terms of staff perceptions, i.e. communication could be improved, processes 
were bureaucratic and people were not feeling optimally motivated (White et al., 2010). To that end, procedures were established to triangulate the data from the three surveys in order to formulate an appropriate action plan to address areas of concern.

This paper is focussed specifically on the organisational agility maturity survey. Given the changing nature of both the higher education and information technology sectors, the INS executive felt it important to set an agility baseline upon which to build in terms of managing change. In addition, the maturity assessment was undertaken to identify areas within the Division in which agility already existed as well as areas with an agility deficit. This knowledge was deemed critical to supporting the divisional goal of constantly seeking to align itself with the University's strategic priorities by having the agility and flexibility to respond to a rapidly changing environment, while remaining effective and efficient.

\subsection{Original survey tool}

An online survey was adopted as the method for this research because it enabled speedy distribution and response cycles (Taylor, 2000), as well as automatic verification and response capture in databases (Andrews et al., 2003).

The survey was based on a questionnaire originally designed by Wendler (2014), which, in turn, was based on a comprehensive literature review and had, as its purpose, "to generate an understanding of organizational agility in a specific industry from a comprehensive and global view" (Wendler and Stahlke, 2014, p. 3). It was administered to "general and IT-related decision-makers (like CEOs, CTOs, Managers, and employees in leading positions) in organizations of the software- and IT service industry worldwide" (Wendler and Stahlke, 2014, p. 4). The questionnaire was carefully pre-tested by academics and practitioners, and ultimately comprised 68 questions. The questions are available in both English and German languages.

In the initial research undertaken by Wendler (2012), he undertook a mapping study of the available literature at the time on maturity models. One of his basic critiques was of the "relatively high number of conceptually developed maturity models without any validation at all" (p. 1332). He concluded that "that there is still a gap in evaluating and validating developed maturity models" (p. 1317).

In the development of his own model (the "Organizational Agility Maturity Model), Wendler (2014) outlined his use of a design science research approach, which included an extensive literature review and empirical investigation. He applied cluster analysis to an exploratory quantitative survey, which was designed to identify the elements of an agile organisation; the results led to the reduction of an initial five maturity stages to four (as shown in Table II). In a later publication, Wendler (2016, pp. 451-459) has discussed in detail the processes he used to validate both the structure that underpins his model and his results.

Wendler (2014) concluded that his model provided a theoretically and empirically grounded structure, that was "suitable to assess and describe the current state of organizational agility and to assist organizations from the software and IT service industry in taking further actions on their path to organizational agility" (p. 1204).

Of particular significance to the authors' current paper is Wendler's (2014) recommendations that:

Further research should strive for additional validation. Of importance would be qualitative indepth analyses, for instance by case studies or action research approaches, to validate the proposed stages as able to deliver helpful information for individual cases. In addition, the survey used to identify the structure of organizational agility, and hence the structure of the maturity model, could be replicated with a different sample in other industries to check if the model is also applicable to other domains (pp. 1204-1205).

These recommendations helped to inform the approach taken at Griffith University. 
A small project team within the planning and engagement portfolio was tasked with designing and administering the INS organisational agility maturity survey. It was agreed that, where possible, the original 2014 survey questions (English version) would be retained without modification. However, a number of modifications were, in fact, introduced in order to meet the survey objectives of the division:

- Because an important objective was to assess perceptions among all staff, regardless of classification level, the survey questions were allocated to two separate questionnaires: Managers and General Staff.

- Because Wendler had found differentiation among managers' responses, the whole of the division needed to be assessed so as to establish a baseline for each of the two major roles, i.e. manager and general staff member.

- Because of the concern about "survey fatigue" among staff, the original 68 questions were reduced to 52 for managers and 40 for general staff.

- Because of some awkward phrasing (perhaps because of the original questions in German having been translated to English), some questions were slightly reworded for ease of understanding.

Wendler (2014) authored his questions for a managerial audience. However, for the reasons identified above, the Griffith project team felt that the questions were best segmented between a "manager" and a "staff" perspective. The questions were then reworded to be appropriate for their target audience.

In addition, Wendler grouped his questions according to six "dimensions". However, the Griffith project team felt that the following six dimensions (Allied Consultants Europe, 2010, p. 5) were more closely aligned with the high-level categories of the other two INS staff surveys mentioned previously:

(1) leadership and management;

(2) innovation;

(3) strategy;

(4) culture;

(5) learning and change; and

(6) structure.

For purposes of granularity in terms of evaluating the survey results, the project team first grouped the questions according to each of the six dimensions listed above and then further categorised them by sub-themes, which were based on what Wendler (2013) referred to as "agility concepts" (p. 1180). Table I shows this structure.

Questions were asked on a five-point Likert scale, based on the original survey. Both surveys used a behaviourist approach, whereby observable behaviour was measured rather than asking for an individual's subjective beliefs (Morrell-Samuels, 2002). According to Wendler and Stahlke (2014):

In our opinion, an organization is not agile when its employees and managers "agree" with statements describing agility or when they "think" they are agile. Instead, it is the actions, capabilities, values, etc. of an organization that represent its agility. So, item-specific scales were developed to measure the dissemination of values and the implementation of conditions (from completely to not at all), the distribution of capabilities among employees and managers (from all to none), and the frequency of activities (from always to never) (p. 4). 
Leadership and management

Innovation

Strategy

Culture

Learning and change

Table I.

Structure

Communication
Risk
Style
Flexibility
Proactivity
Engagement
Industry awareness
Planning
Accountability
Trust
Values and principles
Organisational learning
Skills development
Workforce capability
Adaptability
Collaboration
Cooperation

Both questionnaires were pre-tested before being circulated to the target population.

Appendices 1 and 2 show each of the two questionnaires - Manager and General Staffwith their respective Likert values. Appendix 3 shows how the questions were then grouped by the Griffith project team for evaluation purposes according to the six high-level categories/dimensions (themes) and corresponding sub-themes, as outlined in Table I.

\subsection{Definitions}

According to Wendler (2014, pp. 1201-1202), the four stages of agility maturity are defined in Table II.

\begin{abstract}
Maturity Stage 0-Non-agile
"Organizations at maturity stage 0 show no or only rare properties of organizational agility. Agile values are principally unknown, and the technological basis is fragmented and unable to support communication processes effectively. Only a minority of employees and managers share capabilities necessary to implement agile values and actions"
\end{abstract}

Maturity Stage 2-Agility Transition "Organizations at maturity stage 2 manage to disseminate agile values and to establish an appropriate technological basis in most parts of the organization. Many employees and managers share the idea of agility and possess corresponding capabilities. Change is mostly welcomed and handled accordingly. In many instances, the organization [...] promote(s) teamwork and establishes organizational structures that are flexible enough to cope with upcoming changes"
Maturity Stage 1-Agility Basics

"Organizations at maturity stage 1 share basic properties of organizational agility. Agile values and technological prerequisites underscoring agility are partly implemented in some but not the majority of departments [...] Likewise, some but not the majority of employees share agile capabilities [...] and some managers in the organization are able to manage change in an appropriate way. Often, these employees and managers are 'concentrated' in single teams or departments"

Maturity Stage 3-Organisational Agility

"Organizations at maturity stage $3[\ldots]$ manage to establish a sufficient technological basis throughout the complete organization, and agile values are shared and accepted completely, too. All employees and managers have the capabilities to successfully work in an agile and changing environment [...] and the
Table II.

Four stages of organisational agility maturity 
Following on from Wendler (2014, p. 1200), it was proposed that all sub-themes be treated as equally important and that the overall maturity score be simply the average. To determine the maturity stage of an organisation, Table III was applied, based on the average score calculated for each sub-theme.

\subsection{Target audience identification}

While the Division was comprised of eight official "portfolios", staff within the areas of the pro vice chancellor and her deputy (chief technology officer) were allocated to a ninth portfolio for consistency of reporting.

The survey target audiences were then determined based on the criteria that managers were defined as any staff member who was responsible for the day-to-day activities of staff, including team leaders, line managers, associate and full directors; and "general staff" comprised the remaining pool. Teams were subsequently grouped within portfolios to ensure that they contained five or more staff members, so as to help ensure anonymity. Managers were not grouped as such, but rather were classified into their respective portfolios.

\subsection{Survey tool criteria and selection}

The Employee Life (https://employeelife.com) survey instrument was selected for several reasons. First, it was known to INS staff, as it had been deployed to administer an Employee Engagement Program survey some three months prior to the agility assessment being done. Staff were familiar with the look and feel of the tool, and more importantly, understood that respondent anonymity was assured, as survey data were held by an independent third party. Second, raw data were not provided; rather aggregate responses were reported, which were then mapped to variables such as portfolio (directorate), campus, age range, gender, department (team), position and position level within the Australian Higher Education Worker (HEW) classification structure. Any variable that returned fewer than five responses had its data withheld.

There were some restrictions in setting up the questionnaire for the agility assessment, as the Employee Life tool has been traditionally used to measure employee engagement. Therefore, the tool did not possess (at the time) the same design features as a broadspectrum survey instrument, such as SurveyMonkey. However, Employee Life could offer individual survey logins, which allowed for the capturing of respondent demographics, while at the same time ensuring anonymity. This feature also provided an assurance that respondents would only be able to complete the survey once.

\subsection{Survey distribution and follow-up}

Survey fieldwork was untaken entirely online, with a two and a half week survey window utilised from October 27 through until 13 November 2016. One initial launch e-mail was sent, followed by two reminder e-mails.

The total survey population was 521, which equated to actual staff. The survey generated 299 responses, representing an overall response rate of 66 per cent. The managers' survey had a response rate of 74 per cent (77/104) while the staff survey returned a response rate of 53 per cent (222/417).

\begin{tabular}{ll}
\hline Average score & Maturity stage \\
\hline$(1,2.5)$ & 0: Non-agile \\
$(2.5,3.5)$ & 1: Agility Basics \\
$(3.5,4.5)$ & 2: Agility Transition \\
$(4.5,5)$ & 3: Organisational Agility
\end{tabular}

Table III. Scoring ranges for the four stages of maturity 


\section{JOCM}

Figure 1.

Colour coding for stages of maturity

\subsection{Data extraction and pre-processing}

The Employee Life team provided aggregated data with a total count against each question's Likert values broken down by the different cohort groupings, with each cohort grouping including a total population size as well. This raw data were then entered into a modelling spreadsheet, which converted the Likert count into an average and variance per question/cohort grouping. These were then used to generate the outputs showing the levels of organisational agility maturity across the organisation.

\subsection{Visual representation of data}

Following the pre-processing and data analysis, data were presented in Microsoft Excel by way of a "heat map". An effective and powerful visual presentation of the results was achieved by using a colour coded scale (refer Figure 1) to represent the scores. This displayed "chutes" of mid to high agility, represented by dark green (4.5 and above) and light green (3.5-4.4) cells, and "chutes" of low or non-agility, represented by pink (2.5-2.9) and red $(<2.5)$ cells. This allowed the reader to quickly understand the spread of organisational agility across the organisation, its teams and cohorts as specified by the predefined variables as appended to the population file.

Although these stages of agile maturity are based on the four defined by Wendler in Table II, the INS project team did make one modification. Given that the majority of scores across the Division placed INS in Agility Basics (Stage 1), the team split Stage 1 into two sub-sections. The first sub-section, which was colour coded white, indicated scores in the higher range within Stage 1, i.e. between 3.0 and 3.4; the second sub-section, which was colour coded pink, indicated scores at the lower end, i.e. between 2.5 and 2.9. As noted above, this greater level of granularity was designed to assist senior management in quickly identifying variations across the Division.

\section{Selected results}

Selected descriptive results of the survey are presented in this section. Section 4.1 provides a summary of the results for the whole Division.

\subsection{Overview}

The overall INS result was a score of 3.25, placing the Division in the Agility Basics (Stage 1) maturity model. Figure 2 shows a breakdown of this score when mapped against the six dimensions of the ACE Agility Index (the inner rings), and the sub-themes (the outer rings, as identified by Wendler). Results are for the Division as a whole. As in Figure 1, a colour scheme was used to visually differentiate each of the dimensions so as to help the reader comprehend high-level data in a concise and accessible way.

The six dimensions are represented by the four rings between the black centre and the ring which identifies them, i.e. leadership and management, innovation, strategy, culture, learning and change, and structure. All dimensions - as represented by their unique colour, 


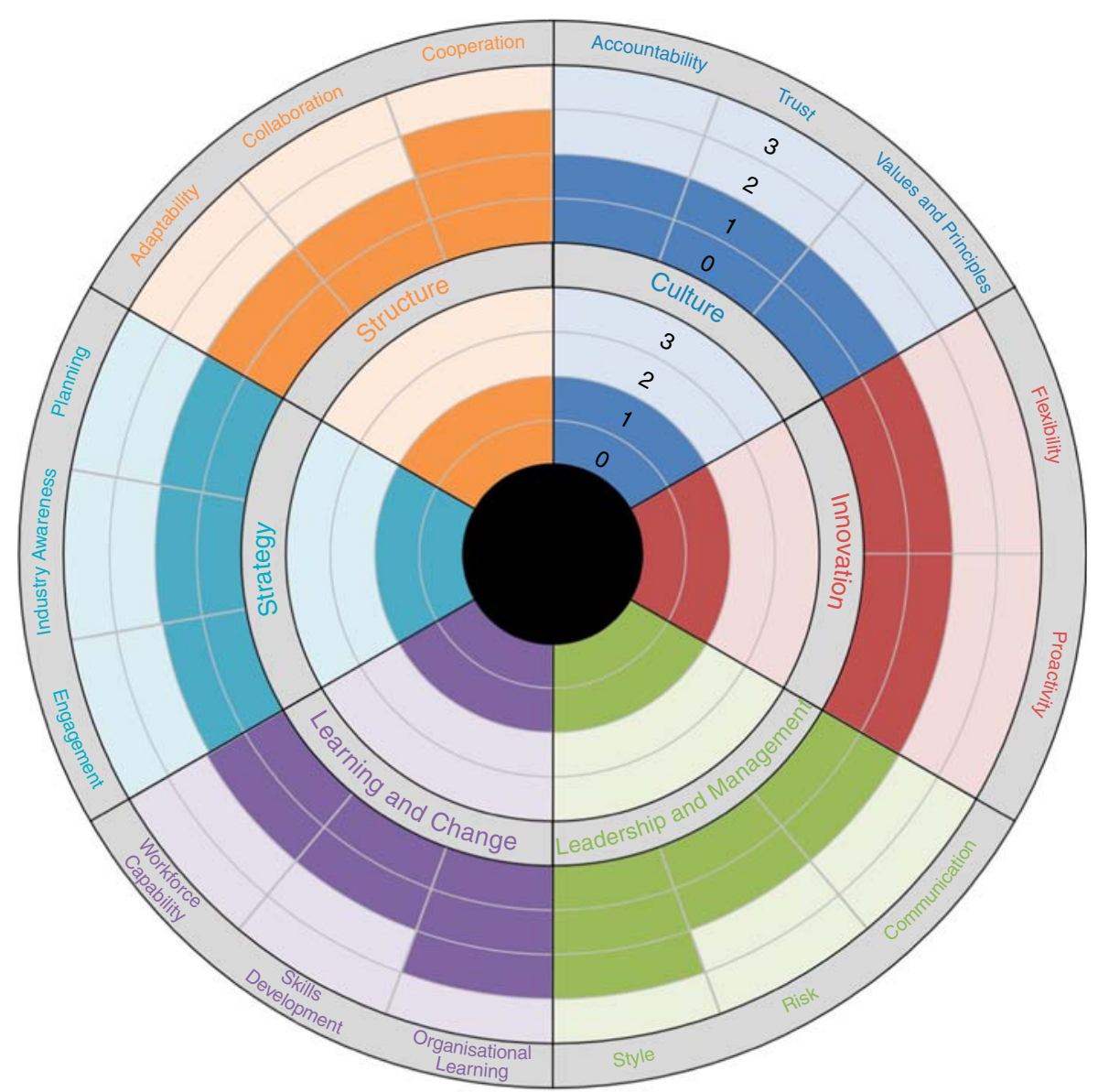

Organisational
agility
maturity model

Notes: Colours plot the level of organisational agility allocated to the four stages, where $0=$ Stage 0 (Non-agile), $1=$ Stage 1 (Agility Basics), $2=$ Stage 2 (Agility Transition) and $3=$ Stage 3 (Organisational Agility). The variation in colours is designed to uniquely identify each of the six dimensions

e.g. orange for structure-scored a maturity level of Stage 1, i.e. Agility Basics, as represented by the number " 1 " near the centre of the chart.

The outer rings - also numbered 0 to 3 , i.e. the stages of agility-represent the dimensions broken down into their component sub-themes, based on Table I. In general, the sub-themes scored at maturity level Stage 1. For example, accountability, trust and values and principles, which are sub-themes of culture - as represented by the colour blue - all fall within the ring numbered " 1 ".

However, cooperation (within structure), style (within leadership and management) and organisational learning (within learning and change) were all allocated an organisational agility maturity score of Stage 2 (Agility Transition). Their corresponding colour is sitting in the ring numbered "2", which is towards the outside of the chart.

Figures 3 and 4 represent a breakdown of the overall INS' agility score (3.25) by the six high-level dimensions. Figure 3 represents the scores for each of the dimensions by staff 
type, i.e. managers and general staff. There was little variation between staff and managers' scores across the Division. In addition, no dimension was rated as non-agile. At the same time, however, no dimension was rated as having reached organisational agility (Stage 3). It should be noted that two dimensions, i.e. learning and change and structure) within the executive group were flagged (via the green colour coding) as having reached Stage 2 (Agility Transition) maturity level. This corroborates Wendler and Stahlke's (2014, p. 30) findings in their survey results that senior executives tended to have a more positive perception of nearly all items than did other roles within an organisation, including participants with managing positions.

Figure 4 represents the scores for each of the dimensions based on the eight official divisional portfolios (P1-P8), with the ninth portfolio (P9) representing the office of the pro vice chancellor, chief technical officer, and their staff.

It shows that there was some variation present between portfolios, with P5, P8 and P9 reporting as most agile, as evidenced by the amount of green colour coding. An overall Stage 2 maturity level (Agility Transition) was allocated to P5 and P9, with scores of 3.5 and 3.68 , respectively. P8's score of 3.49 fell just short of the 3.5 threshold to be officially scored as having Stage 2 maturity. As in the case of Figure 3, it should be noted that the comparatively high scores by Portfolio 9 are in line with Wendler and Stahlke's findings regarding scoring by senior executives.

P1, P2 and P3 recorded the lowest scores, albeit still within the Stage 1 (Agility Basics) maturity level. No portfolio had an overall score below a mean of 3.0, which was a threshold INS used to flag those areas (via the pink colour coding) which were at the lower bracket of the Agility Basics scoring spectrum.

\subsection{Differentiated results}

The survey questionnaire for both surveys was divided into three parts: the first asked questions about INS at a divisional level (Tranche 1), the second asked about the managers

Figure 3.

Overview of managers and general staff's scores
Figure 4.

Comparison between the scores of the INS portfolios

\begin{tabular}{|c|c|c|c|c|c|c|c|}
\hline \multirow[b]{2}{*}{ Theme } & \multirow{2}{*}{$\begin{array}{c}\text { INS } \\
\text { INS as } \\
\text { a } \\
\text { whole }\end{array}$} & \multicolumn{3}{|c|}{ Staff/Manager } & \multicolumn{3}{|c|}{ Staff Type } \\
\hline & & $\begin{array}{l}\text { INS } \\
\text { Staff }\end{array}$ & \multicolumn{2}{|c|}{$\begin{array}{l}\text { INS } \\
\text { Managers Variance }\end{array}$} & $\begin{array}{l}\text { Genera } \\
\text { Staff }\end{array}$ & $\begin{array}{l}\text { General } \\
\text { Manager }\end{array}$ & xecutive \\
\hline Overall & 3.25 & 3.27 & 3.20 & 0.07 & 3.25 & 3.17 & 3.37 \\
\hline Culture & 3.23 & 3.27 & 3.11 & 0.15 & 3.24 & 3.07 & 3.37 \\
\hline Innovation & 3.05 & 3.09 & 3.01 & 0.08 & 3.06 & 2.98 & 2.17 \\
\hline Leadership and Management & 3.36 & 3.40 & 3.21 & 0.19 & 3.37 & 3.17 & 3.42 \\
\hline Learning and Change & 3.38 & 3.32 & 3.47 & 0.15 & 3.30 & 3.46 & 3.51 \\
\hline Strategy & 3.14 & 3.16 & 3.12 & 0.04 & 3.15 & 3.09 & 3.27 \\
\hline Structure & 3.21 & 3.19 & 3.28 & 0.10 & 3.17 & 3.24 & 3.51 \\
\hline
\end{tabular}

\begin{tabular}{|c|c|c|c|c|c|c|c|c|c|}
\hline \multirow[b]{2}{*}{ Theme } & \multicolumn{9}{|c|}{ Portfolio } \\
\hline & $\mathrm{P} 1$ & $\mathrm{P} 2$ & P3 & $\mathrm{P} 4$ & P5 & P6 & P7 & P8 & P9 \\
\hline Overall & 3.12 & 3.07 & 3.06 & 3.25 & 3.50 & 3.27 & 3.32 & 3.49 & 3.68 \\
\hline Culture & 3.06 & 3.02 & 2.98 & 3.24 & 3.55 & 3.24 & 3.38 & 3.50 & 3.62 \\
\hline Innovation & 2.84 & 2.83 & 3.03 & 3.19 & 3.04 & 3.01 & 3.12 & 3.24 & 3.58 \\
\hline Leadership and Management & 3.17 & 3.24 & 3.15 & 3.30 & 3.68 & 3.39 & 3.44 & 3.68 & 3.77 \\
\hline Learning and Change & 3.42 & 3.18 & 3.27 & 3.24 & 3.42 & 3.40 & 3.39 & 3.76 & 3.71 \\
\hline Strategy & 2.96 & 2.88 & 2.99 & 3.26 & 3.31 & 3.30 & 3.12 & 3.25 & 3.97 \\
\hline Structure & 3.17 & 3.13 & 3.00 & 3.24 & 3.49 & 3.11 & 3.31 & 3.37 & 3.46 \\
\hline
\end{tabular}


in the respondent's area (Tranche 2), and the third asked about the staff within the respondent's area (Tranche 3 ).

Figure 5 shows these three groupings and their scores for a typical team within INS, which is an indicative result for the whole Division. Each of the 40 general staff survey questions has been allocated to one of the three groupings. The results show that respondents scored organisational maturity quite harshly when thinking at the Divisional level. When respondents considered the managers within their own area, scores were overwhelming positive. When scoring organisational maturity levels of staff within the respondent's areas - that is, their peers - the results were still positive, but less so than when compared with scores for their managers.

In regard to other survey results, there was little variation in scores across the five campuses. In terms of seniority, staff at the HEW 3 and HEW 4 classification levels saw more organisational agility maturity than others; however, for levels HEW 5 and above, there was minimal variance.

Females responding to the staff survey rated organisational agility maturity as being more advanced than males did. While the Division had a relatively equal gender split overall (44 per cent female/56 per cent male), there was less diversity when looking at the library and IT areas separately. For the library, 84 per cent of staff were female and 16 per cent were male. For the IT areas, the trend was reversed, with females only accounting for 33 per cent of staff, whereas males comprised 66 per cent. The fact that female staff rated organisational agility maturity as being higher than males would seem to indicate that the library was exhibiting more agility traits than the IT areas.

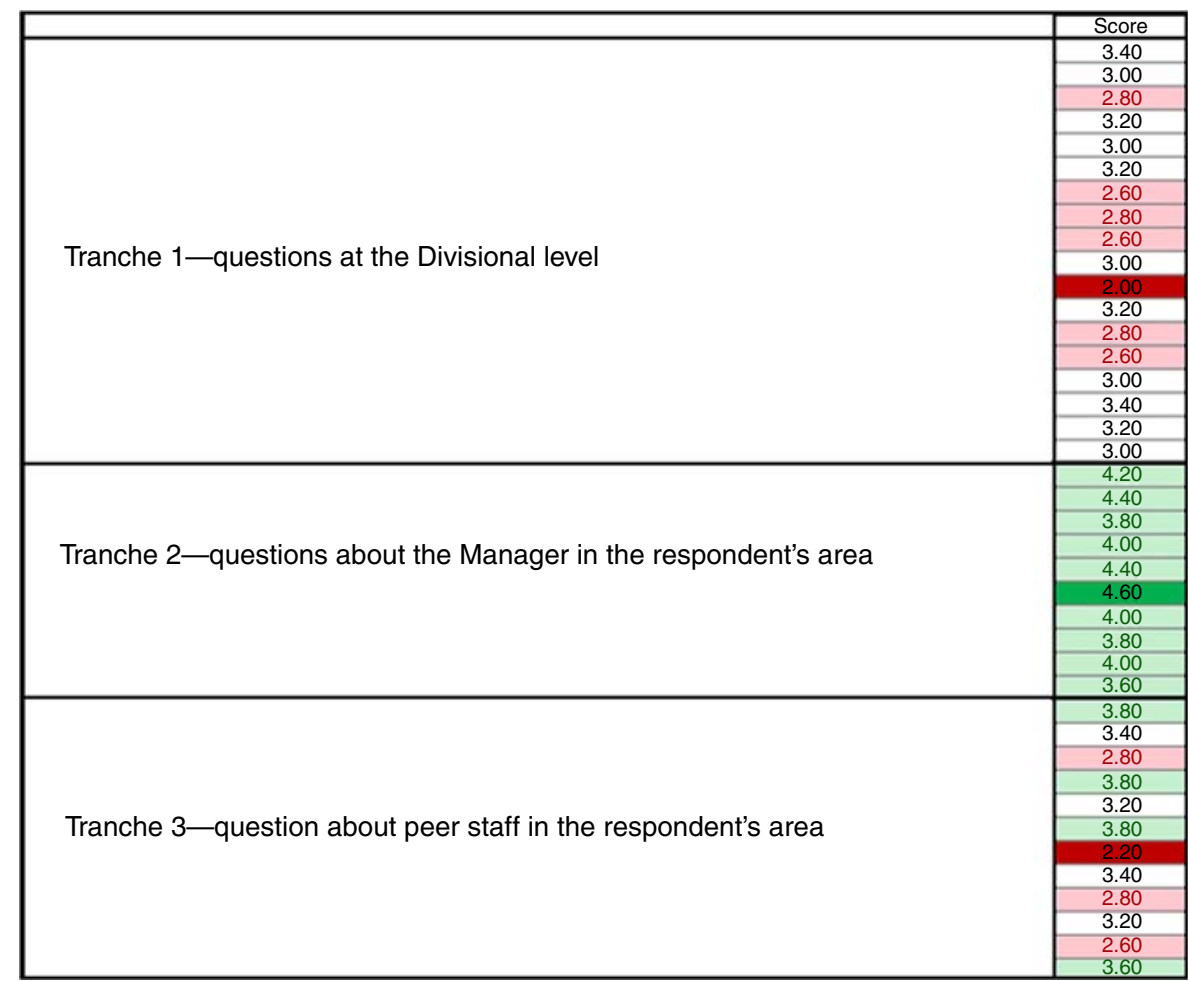

Organisational agility maturity model 
It was also possible to drill down into a specific dimension, by displaying the results of the contributing sub-themes. Figure 6 shows the scores for the Division broken down by the respective sub-themes. As was illustrated in Figure 2 (radar chart), three sub-themes were allocated an organisational agility maturity score of Stage 2 (Agility Transition); these are indicated by the green colour coding.

Figure 7 is a team "league table" of staff results by the overall mean. Results are displayed, indicating whether a team was a front-line (client-facing) or back-end (non-client-facing) service provider. The portfolio to which each team belongs is indicated by the value in parentheses.

The highest team result was an overall mean score of 3.9; the lowest team result was an overall mean of 2.63 .

Back-end teams had a higher agility score than front-end teams. Of the seven teams which were rated at Stage 2 (Agility Transition), four were back-end teams. Of the ten teams which were rated at Stage 1 (Agility Basics), six were back-end teams. When looking at the teams which scored a mean of less than 3 , six of the seven were client-facing teams.

The spread of portfolios was relatively even across the middle and upper scoring teams; however, when looking at the teams which scored below a mean of $3, \mathrm{P} 6$ had four of the seven positions.

As per Figure 4 (which showed portfolio-level results), no team was rated as being nonagile. However, no team was allocated a Stage 3 rating of Organisational Agility either. Breaking the team results down shows that:

- seven teams were rated at Stage 2 maturity, i.e. Agility Transition;

- ten teams were rated at Stage 1 maturity, i.e. Agility Basics;

- seven teams were rated at Stage 1 maturity (Agility Basics), but with a mean score of $<3$; and

- six teams received no rating, as they did not register a minimum of five responses and therefore had their results withheld.

Figure 6.

Example of overall scoring for dimensions and their sub-themes

\begin{tabular}{|c|c|c|}
\hline \multirow[b]{2}{*}{ Dimension } & \multirow[b]{2}{*}{ Sub-theme } & INS \\
\hline & & $\begin{array}{c}\text { INS as } \\
\text { a } \\
\text { whole }\end{array}$ \\
\hline \multirow{3}{*}{ Culture } & Accountability & 3.50 \\
\hline & Trust & 3.11 \\
\hline & Values and Principles & 3.11 \\
\hline \multirow{2}{*}{ Innovation } & Flexibility & 3.03 \\
\hline & Proactivity & 3.07 \\
\hline \multirow{3}{*}{ Leadership and Management } & Communication & 3.25 \\
\hline & Risk & 3.44 \\
\hline & Style & 3.51 \\
\hline \multirow{3}{*}{ Learning and Change } & Organisational Learning & 3.67 \\
\hline & Skills Development & 3.18 \\
\hline & Workforce Capability & 3.48 \\
\hline \multirow{3}{*}{ Strategy } & Engagement & 3.08 \\
\hline & Industry Awareness & 3.18 \\
\hline & Planning & 3.13 \\
\hline \multirow{3}{*}{ Structure } & Adaptability & 3.08 \\
\hline & Collaboration & 3.07 \\
\hline & Cooperation & 3.60 \\
\hline
\end{tabular}



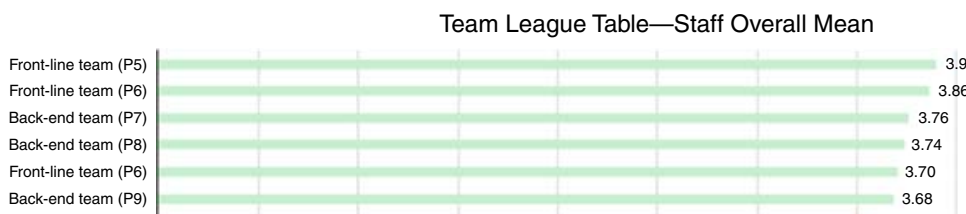

\begin{tabular}{l|c|} 
Back-end team (P9) & 3.68 \\
Back-end team (P1) & 3.58
\end{tabular}

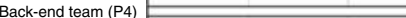

Front-line team (P6) 3.38

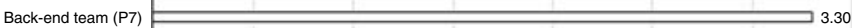

Back-end team (P7)

Front-line team (P8)

Front-line team (P5)

Back-end team (P2)

Front-line team $(P 3)$

Back-end team (P2)

Back-end team (P4)

Front-line team (P6)

Front-line team $(\mathrm{P} 6)$

Front-line team (P3)

Front-line team (P6)

Front-line team (P6)

Back-end team (P1)

Front-line team (P3)

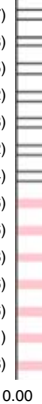

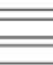
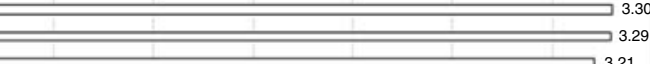

2.30
2.29
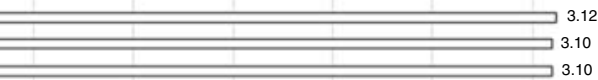

$\longrightarrow .04$

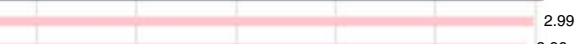

\begin{tabular}{c|c|c|c|c|} 
& 2.89 \\
- & 2.85
\end{tabular}

\begin{tabular}{|c|c|c|}
\hline & & 2.79 \\
\hline
\end{tabular}

0.50

\section{Discussion}

The purpose of this research study was to identify the most appropriate organisational agility maturity model that could be applied to an information technology service division within a university. Based on an analysis of the extant literature, the authors selected Wendler's Organizational Agility Maturity Model as the most suitable tool (Wendler, 2014).

The authors then proposed three research questions, for which the following results were identified:

$R Q 1$. Is Wendler's organisational agility maturity model applicable to an information technology (IT) service division within a university?

The main findings for this research confirm the general applicability of Wendler's model to the higher education sector. However, in applying the model, the authors discovered that considerably more work was required, than originally anticipated, to adapt the questionnaire to meet the needs of the division. The reasons were twofold. First, as Krell (2011, p. 97) has observed, "Bias exists in all forms of manager-employee interactions". Therefore, a desire to balance the impact of potential bias among managers and general staff led to the design of separate surveys for each group, rather than simply administering Wendler's original questionnaire, which had been designed only for managers. Second, the amount of data generated by the survey led to lengthy discussions about how to visualise the data in a variety of ways that could encapsulate high-level themes as well as expose issues at a more granular level, and also provide for correlation of the data with the results from the two other surveys mentioned previously, i.e. engagement and culture.

Applying the survey model, as outlined in this paper, will provide a university IT service division with a baseline maturity-level score. However, in the case of INS, the overall score of 3.25-Agility Basics (Stage 1), while at best an interesting reference point-was a score which offered little in diagnosing the actual maturity level of the individual elements within the organisational structure, i.e. the portfolios and their respective teams. It was only when results were interrogated at a portfolio and team level that the true picture emerged. It is when working at this more granular level 
that pockets of agility maturity and, indeed, pockets of non-agile practices can be identified, understood and addressed, as appropriate:

$R Q 2$. Is such a model equally suitable for administering across staff at all levels of the organisation?

In analysing the results of the original survey, Wendler and Stahlke (2014) reported on noticeable variations when comparing the answers given by respondents in different managerial roles, for example:

CEOs seem to have a much more positive perception of nearly all items than other roles in an organization. This is surprising because all participants had managing or at least leading positions in their organizations and thus were able to answer the items from a comprehensive perspective. Although it is appropriate to assess agility from an organizational view, it still raises the question of whether other employees, for instance programmers or consultants, would show different results (p. 30).

The results of the current study also showed differentiated results, particularly among general staff. For example, as reported in Figure 7, from the perspective of teams, those which were client facing generally had lower agility scores than those which were nonclient facing.

While providing considerable granular data, the results raised a number of questions for further investigation. A key consideration, for example, is the potential impact of organisational structure. In an organisation in which most units are structured on the basis of function, multiple units are required for end-to-end business processes. If, in a given functional area, one unit achieves a high score in Stage 2 (Agility Transition) but the other units score at mid to low range within Stage 1 (Agility Basics), what implications can be drawn? Further research is indicated as to whether organisational unit structure can be a limiting factor in achieving organisational agility:

RQ3. Is any additional information required to fully assess the overall maturity of the agility of a university's IT service division?

A post-analysis of the survey did not reveal any issues with any of the questions. However, while, in general, senior INS management had an intuitive feeling as to how the organisation would score, nevertheless, some areas were more agile than expected and other areas produced counterintuitive results. In addition, as was shown in the case of Figure 5, scores varied markedly among divisional teams depending upon whether staff members were responding to questions about the Division, their respective manager or their peers. Given that although the survey was not based on employee satisfaction, it was based on employee perceptions, management recognised the importance of being able to triangulate the data so as to better understand any apparent anomalies. As Wendler (2016, p. 442) has observed, "Incompatibilities between agile methods and organizational culture may occur; therefore, one has to understand and consider the organizational context". Therefore, whereas Wendler's model provides considerable useful data, ideally organisations should incorporate other data to achieve a more in-depth perspective.

Triangulation involves "corroborating data from multiple perspectives to enhance the depth of understanding of a particular theme and to provide verification" (Stavros and Westberg, 2009, p. 307). Beverland and Lindgreen (2010, p. 57) have suggested that triangulation is fundamental to ensuring quality in case studies. To validate the findings from the organisational agility survey, management administered two other surveysemployee engagement and workplace culture. At time of writing, this triangulation has yet to be completed. 


\subsection{Practical implications}

This study makes a theoretical contribution by extending the previous literature on organisational agility maturity models and also presents some useful insights for managers. First, the effort expended by a university IT services division to apply Wendler's model will result in an instrument that not only provides a lot of rich data but also can be re-used over several years as a benchmark against which to assess progress. Second, the types of data visualisation shown in this study should be considered as important tools for presenting complex data in a concise and accessible way, especially to senior management. Third, management should consider what other data gathering initiatives it would wish to employ to supplement Wendler's model.

Fourth, an important aspect of the environment in which the current survey was administered was staff awareness of impending transformative changes within the University and, by extension, the Division. Senior INS management had already used a variety of communication channels to promote the need to embrace change as a constant and to become more agile as a response. Therefore, in theory, the survey should not have come as a surprise to staff. Clearly there were different perceptions among staff as to what constituted "agility", especially in areas which were already practicing agile project methodology. However, for a survey of this type to provide real return on investment to an organisation, managers are advised to introduce all staff to the concept of agility, and more especially organisational agility, before the survey is administered. As the literature review has demonstrated, organisational agility is a nuanced concept; it takes time for those who are familiar with agile project methodology to appreciate the broader environment in which a whole-of-organisation approach needs to be considered.

Finally, from these observations, it is readily apparent that the action plan an organisation develops as a response to this survey is an important output. In the specific case of INS, one of the portfolio managers used the results in her area to inform structural transformation. Ideally the development of such a plan should be based on an appropriate, defined target state. The action plan should focus on those work areas in which the survey has identified an agility deficit. At the same time, it is important to recognise that the achievement of desired outcomes across separate areas within the organisation may require different actions, based upon the culture of each of those areas.

\subsection{Limitations}

One of the limitations of applying Wendler's model as outlined in this case study is that Employee Life was the selected survey tool. Using a broad-spectrum survey instrument, such as SurveyMonkey, would possibly require a different approach to the design of the questionnaire and the extraction of data.

A university IT services division does not sit in isolation within the parent organisation. While INS had a history of trying to understand its own environmental factors, it did not know the level of influence of external environmental factors. These include, but are not limited to, university organisational structure, governance and resource constraints; human resource issues, such as staff turnover and performance management; and the enterprise's perspective on key issues, such as risk tolerance. The compilation of additional data within this broader framework could help to better contextualise the data derived from the current survey.

Finally, the grouping of survey questions under particular broad themes reflected the strategic focus of the division being surveyed. Organisations implementing the proposed model would need to select themes that corresponded with their respective strategic goals and culture.

\section{Conclusion}

The higher education industry is evolving at an ever-accelerating pace. As a result, university information technology services must be able to support their clients with an 
effective balance of leadership, guidance and high-quality service delivery. IT services are constantly seeking to align themselves with their university's strategic priorities by having the agility and flexibility to respond to a rapidly changing environment, while remaining effective and efficient. Organisational agility is seen as a strategic imperative for achieving these goals.

In this paper, the authors have extended the work of Wendler (2014) by expanding his organisational agility maturity model in two ways: they have applied it specifically to a university information services division and to both managers and general staff (employees). Having undertaken a self-assessment exercise using the maturity model, the next step for Griffith University is to triangulate the survey results within a broader framework that incorporates employee engagement and organisational culture as key pillars in the better enablement of agility, flexibility and alignment of services.

This study presents opportunities for further research. First, as highlighted previously, additional research is indicated as to whether organisational unit structure may be a limiting factor in achieving organisational agility. Second, the case subject was a medium-sized university in Australia. Future research should compare the results from surveying similarly sized universities from different regions in the world and differently sized higher education institutions. Third, more research could be undertaken to compare the results of different organisational roles within university IT service divisions. Finally, more research is needed to extend the applicability of Wendler's model to a wider range of domains and industries.

\section{References}

Adams Becker, S., Cummins, M., Davis, A., Freeman, A., Hall Giesinger, C. and Ananthanarayanan, V. (2017), "NMC Horizon Report: 2017 Higher Education Edition", The New Media Consortium, Austin, TX.

Aghina, W., De Smet, A. and Weerda, K. (2015), “Agility: it rhymes with stability”, McKinsey Quarterly, December, pp. 1-12, available at: https://meincoach.at/pdfs/agility_rhymes_with_stability_20 1512_McK.pdf (accessed 31 July 2017).

Allen, M. (2014), Aha Moments in Talent Management, ASTD Press, Alexandria, VA.

Allied Consultants Europe (2010), "Organisational agility - the new normal", Allied Consultants Europe, Stuttgart, available at: www.ace-alliedconsultants.org/publications/files/2010-aceorganisational-agility (accessed 31 July 2017).

Al-Saleem, S.M. and Ullah, H. (2015), "A comparative analysis and evaluation of different agile software development methodologies", International Journal of Computer Science and Network Securitv, Vol. 15 No. 7, pp. 39-45.

Andrews, D., Nonnecke, B. and Preece, J. (2003), "Electronic survey methodology: a case study in reaching hard-to-involve internet users", International Iournal of Human-Computer Interaction, Vol. 16 No. 2, pp. 185-210.

Aronowitz, S., De Smet, A. and McGinty, D. (2015), “Getting organizational redesign right”, McKinsey Quarterly, June, pp. 1-11, available at: www.ohisolution.com/media/16083/Gettingorganizational-redesign-right_McK-Quarterly_June2015.pdf (accessed 31 July 2017).

Beck, K., Beedle, M., Van Bennekum, A., Cockburn, A., Cunningham, W., Fowler, M. and Kern, J. (2001), "Manifesto for agile software development", available at: http://agilemanifesto.org/principles. html (accessed 31 July 2017).

Beverland, M.B. and Lindgreen, A. (2010), "What makes a good case study? A positivist review of qualitative case research published in Industrial Marketing Management, 1971-2006", Industrial Marketing Management, Vol. 39 No. 1, pp. 56-63.

Bottani, E. (2009), “On the assessment of enterprise agility: issues from two case studies”, International Lournal of Logistics, Vol. 12 No. 3, pp. 213-230. 
Bottani, E. (2010), "Profile and enablers of agile companies: an empirical investigation", International Journal of Production Economics, Vol. 125 No. 2, pp. 251-261.

Charbonnier-Voirin, A. (2011), "The development and partial testing of the psychometric properties of a measurement scale of organizational agility", Management, Vol. 14 No. 2, pp. 120-155.

De Smet, A., Lund, S. and Schaninger, W. (2016), "Organizing for the future”, McKinsey Quarterly, January, pp. 1-14.

Desouza, K. (2006), Agile Information Systems: Conceptualization, Construction and Management, Routledge, London.

Dingsøyr, T., Nerur, S., Balijepally, V. and Moe, N.B. (2012), "A decade of agile methodologies: towards explaining agile software development", Journal of Sustems and Software, Vol. 85 No. 6, pp. 1213-1221.

Gartner (2006), “Achieving agility: defining agility in an IT context”, available at: www.gartner.com/ doc/491393?ref=ddisp (accessed 31 July 2017).

Gerring, J. (2004), "What is a case study and what is it good for?", American Political Science Review, Vol. 98 No. 2, pp. 341-354.

Gustafsson, J. (2017), "Single case studies vs multiple case studies: a comparative study", available at: www.diva-portal.org/smash/get/diva2:1064378/FULLTEXT01.pdf (accessed 31 July 2017).

Harraf, A. and Tate, K. (2014), "Attributes of agile organizations", paper presented at 2014 AABRI International Conference, Honolulu, HI, 12-14 June, available at: www.aabri.com/HC20 14Manuscripts/HC14036.pdf (accessed 31 July 2017).

Holbeche, L. (2015), The Agile Organization: How to Build An Innovative, Sustainable and Resilient Business, Kogan Page Publishers, London.

Ionel, N. (2009), "Agile software development methodologies: an overview of the current state of research", Annals of the University of Oradea, Economic Science Series, Vol. 18 No. 4, pp. 381-385.

Kassim, N.M. and Zain, M. (2004), "Assessing the measurement of organizational agility”, The Journal of American Academy of Business, Vol. 4 Nos 1/2, pp. 174-177.

Krell, E. (2011), “An impartial review”, HR Magazine-Alexandria, Vol. 56 No. 10, pp. 97-99.

Lu, Y. and Ramamurthy, K. (2011), "Understanding the link between information technology capability and organizational agility: an empirical examination", MIS Quarterlv, Vol. 35 No. 4, pp. 931-954.

Manpower (2014), “2014 organisational agility survey key findings - Australia \& New Zealand”, available at: www.manpowergroup.com.au/documents/White-Papers/2014_organisationalagility-survey.pdf (accessed 31 July 2017).

Maurer, F. and Hellmann, T.D. (2013), "People-centered software development: an overview of agile methodologies", in De Lucia, A. and Ferrucci, F. (Eds), Software Engineering, Springer, Berlin, pp. 185-215.

Meyer, C.B. (2001), "A case in case study methodology”, Field Methods, Vol. 13 No. 4, pp. 329-352.

Morrel-Samuels, P. (2002), "Getting the truth into workplace surveys", Harvard Business Review, Vol. 80 No. 2, pp. 111-118.

Norton, D., Hotle, M., Mesaglio, M., Fitzgerald, D., Swanton, B. and Wilson, N. (2014), Best Practices for Implementing Enterprise Agile Principles, Gartner, Stamford, CT.

Quacquarelli Symonds (2017), “QS University Rankings: Top 50 Under 50 2017-2018”, Top universities, available at: www.topuniversities.com/university-rankings/top-50-under-50/2018 (accessed 22 January 2018).

Rigby, D., Sutherland, J. and Takeuchi, H. (2016), "Embracing agility: how to master the process that's transforming management", Harvard Business Review, Vol. 94 No. 5, pp. 40-50.

Rothschild, H. (2015), "8 vital best business practices", Wealth Professional, 8 September, available at: www.wealthprofessional.com.au/news/8-vital-best-business-practices-205122.aspx (accessed 31 July 2017). 
Sahota, M. (2013), "An organizational transformation checklist”, Agile Alliance, Corryon, TN, available at: www.agilealliance.org/wp-content/uploads/2016/02/An_Organizational_ Transformation_Checklist.pdf (accessed 31 July 2017).

Sherehiy, B., Karwowski, W. and Layer, J.K. (2007), "A review of enterprise agility: concepts, frameworks, and attributes", International Journal of Industrial Ergonomics, Vol. 37 No. 5, pp. $445-460$.

Stavros, C. and Westberg, K. (2009), "Using triangulation and multiple case studies to advance relationship marketing theory", Qualitative Market Research: An International Journal, Vol. 12 No. 3, pp. 307-320.

Taylor, H. (2000), "Does internet research work? Comparing electronic surveys results with telephone survey”, International Journal of Market Research, Vol. 42 No. 1, pp. 51-63.

Tsourveloudis, N.C. and Valavanis, K.P. (2002), "On the measurement of enterprise agility", Journal of Intelligent and Robotic Systems, Vol. 33 No. 3, pp. 329-342.

Wendler, R. (2012), "The maturity of maturity model research: A systematic mapping study", Information and Software Technology, Vol. 54 No. 12, pp. 1317-1339.

Wendler, R. (2013), "The structure of agility from different perspectives", 2013 Federated Conference on Computer Science and Information Systems (FedCSIS), IEEE, September, Kraków, Poland, pp. 1177-1184.

Wendler, R. (2014), "Development of the organizational agility maturity model”, 2014 Federated Conference on Computer Science and Information Systems (FedCSIS), IEEE, Warsaw, Poland, pp. 1197-1206.

Wendler, R. (2016), "Dimensions of organizational agility in the software and IT service industry: insights from an empirical investigation", Communications of the Association for Information Systems, Vol. 39 No. 1, pp. 439-482.

Wendler, R. and Stahlke, T. (2014), "What constitutes an agile organization? Descriptive results of an empirical investigation”, Dresdner Beiträge zur Wirtschaftsinformatik No. 68/14, Technische Universität Dresden, Dresden, available at: http://nbn-resolving.de/urn:nbn:de:bsz:14-qucosa130916 (accessed 31 July 2017).

White, C., Vanc, A. and Stafford, G. (2010), "Internal communication, information satisfaction, and sense of community: the effect of personal influence", Journal of Public Relations Research, Vol. 22 No. 1, pp. 65-84.

Yin, R.K. (1984), Case Study Research: Design and Methods, Sage, Newbury Park, CA.

Zainal, Z. (2007), "Case study as a research method”, Jurnal Kemanusiaan, Vol. 5 No. 1, pp. 1-6, available at: www.jurnal-kemanusiaan.utm.my/index.php/kemanusiaan/article/view/165 


\section{Appendix 1. Survey questions-Managers question set}

The questions listed below were utilised in the survey instrument and presented for managers to complete

\begin{tabular}{|c|c|c|}
\hline Order & Question Text & Scale \\
\hline 1 & $\begin{array}{l}\text { Information Services values a culture that considers teamwork as } \\
\text { an integral part }\end{array}$ & (1) not at all - (5) completely \\
\hline 2 & $\begin{array}{l}\text { Information Services values a culture that considers changing } \\
\text { customer-related requirements as opportunities }\end{array}$ & (1) not at all - (5) completely \\
\hline 3 & $\begin{array}{l}\text { Information Services values a culture that nurtures an } \\
\text { environment where people trust and respect each other }\end{array}$ & (1) not at all - (5) completely \\
\hline 4 & $\begin{array}{l}\text { Information Services values a culture that embraces accountability } \\
\text { from top to bottom }\end{array}$ & (1) not at all - (5) completely \\
\hline 5 & $\begin{array}{l}\text { Information Services prefers a proactive continuous improvement } \\
\text { rather than reacting to crisis or "fire-fighting" }\end{array}$ & (1) not at all - (5) completely \\
\hline 6 & $\begin{array}{l}\text { Information Services prefers flat hierarchies or simple structures } \\
\text { to eliminate barriers between individuals and/or teams }\end{array}$ & (1) not at all - (5) completely \\
\hline 7 & $\begin{array}{l}\text { Information Services prefers simplicity, i.e. skipping product and/ } \\
\text { or service features that go beyond the customer requirements }\end{array}$ & (1) not at all - (5) completely \\
\hline 8 & Information Services prefers a values-based leadership approach & (1) not at all - (5) completely \\
\hline 9 & Information Services prefers transparency of information for staff & (1) not at all - (5) completely \\
\hline 10 & $\begin{array}{l}\text { Information Services prefers implementation of guiding principles } \\
\text { with clear direction, so that all staff understand their contribution }\end{array}$ & (1) not at all - (5) completely \\
\hline 11 & $\begin{array}{l}\text { Information Services has a process for managing suggestions for } \\
\text { improvement, new ideas, and solutions from all levels }\end{array}$ & (1) not at all - (5) completely \\
\hline 12 & $\begin{array}{l}\text { Information Services has staff that have a good understanding of } \\
\text { how their own job relates to INS' overall }\end{array}$ & (1) not at all - (5) completely \\
\hline 13 & $\begin{array}{l}\text { Information Services has a strategic approach which fosters } \\
\text { learning as a crucial element }\end{array}$ & (1) not at all - (5) completely \\
\hline 14 & $\begin{array}{l}\text { Information Services has information systems and technologies } \\
\text { that make organisational information easily accessible to all staff }\end{array}$ & (1) not at all - (5) completely \\
\hline 15 & $\begin{array}{l}\text { Information Services has information systems and technologies } \\
\text { that provide information helping our staff to quickly respond to } \\
\text { change }\end{array}$ & (1) not at all - (5) completely \\
\hline 16 & $\begin{array}{l}\text { Information Services has information systems and technologies } \\
\text { that enable decentralisation in decision making }\end{array}$ & (1) not at all - (5) completely \\
\hline 17 & $\begin{array}{l}\text { Information Services has information systems and technologies } \\
\text { that are standardised or comparable among different } \\
\text { departments and/or business units }\end{array}$ & (1) not at all - (5) completely \\
\hline 18 & $\begin{array}{l}\text { Information Services has information systems and technologies } \\
\text { that provide rapid feedback on operations and keep intelligence } \\
\text { on changing conditions }\end{array}$ & (1) not at all - (5) completely \\
\hline 19 & $\begin{array}{l}\text { Information Services managers within my portfolio maintain an } \\
\text { informal management style with focus on coaching and inspiring } \\
\text { people }\end{array}$ & (1) none - (5) all \\
\hline 20 & $\begin{array}{l}\text { Information Services managers within my portfolio quickly } \\
\text { implement changes in products and/or services }\end{array}$ & (1) none - (5) all \\
\hline 21 & $\begin{array}{l}\text { Information Services managers within my portfolio recognise } \\
\text { opportunities for innovation in products, services and/or } \\
\text { processes which will deliver benefits for the University }\end{array}$ & (1) none - (5) all \\
\hline 22 & $\begin{array}{l}\text { Information Services managers within my portfolio flexibly deploy } \\
\text { their resources (material, financial, human ....) to make use of } \\
\text { opportunities and minimise threats }\end{array}$ & (1) none - (5) all \\
\hline
\end{tabular}

Organisational agility maturity model 


\section{JOCM}

\begin{tabular}{|c|c|c|}
\hline 23 & $\begin{array}{l}\text { Information Services managers within my portfolio acknowledge } \\
\text { and tolerate ambiguity }\end{array}$ & (1) none - (5) all \\
\hline 24 & $\begin{array}{l}\text { My staff sense, perceive, or anticipate the best opportunities } \\
\text { which come up in our environment }\end{array}$ & (1) none - (5) all \\
\hline 25 & $\begin{array}{l}\text { My staff have a broad range of skills which can be applied to other } \\
\text { tasks when needed }\end{array}$ & (1) none - (5) all \\
\hline 26 & $\begin{array}{l}\text { My staff are willing to learn and are prepared to constantly access, } \\
\text { apply and update knowledge }\end{array}$ & (1) none - (5) all \\
\hline 27 & $\begin{array}{l}\text { My staff are willing to continuously learn from one another and to } \\
\text { pass their knowledge to others }\end{array}$ & (1) none - (5) all \\
\hline 28 & $\begin{array}{l}\text { My staff can re-organise continuously in different team } \\
\text { configurations to meet changing requirements and the newly } \\
\text { arising challenges }\end{array}$ & (1) none - (5) all \\
\hline 29 & My staff are self-motivated & (1) none - (5) all \\
\hline 30 & $\begin{array}{l}\text { My staff are prepared to take responsibility for their own } \\
\text { decisions }\end{array}$ & (1) none - (5) all \\
\hline 31 & My staff acknowledge mistakes quickly & (1) none - (5) all \\
\hline 32 & $\begin{array}{l}\text { My staff collaborate closely with different teams and across } \\
\text { portfolios }\end{array}$ & (1) never - (5) always \\
\hline 33 & My staff work in small teams in their projects & (1) never - (5) always \\
\hline 34 & $\begin{array}{l}\text { My staff rotate among different activities, tasks, positions or } \\
\text { departments }\end{array}$ & (1) never - (5) always \\
\hline 35 & $\begin{array}{l}\text { Regarding Information Services staff, we trust them to get their } \\
\text { job done }\end{array}$ & (1) never - (5) always \\
\hline 36 & $\begin{array}{l}\text { Regarding Information Services staff, we offer reward \& } \\
\text { recognition not only for individuals, but for the team and their } \\
\text { contribution to the overall organisation }\end{array}$ & (1) never - (5) always \\
\hline 37 & $\begin{array}{l}\text { Regarding Information Services staff, we encourage our staff to } \\
\text { upgrade their skills and training }\end{array}$ & (1) never - (5) always \\
\hline 38 & $\begin{array}{l}\text { Regarding Information Services staff, we encourage staff at lower } \\
\text { levels to make decisions and take responsibility }\end{array}$ & (1) never - (5) always \\
\hline 39 & $\begin{array}{l}\text { Regarding Information Services staff, we provide opportunities for } \\
\text { staff to multi-skill staff, e.g. job rotation, job mobility }\end{array}$ & (1) never - (5) always \\
\hline 40 & $\begin{array}{l}\text { Regarding Information Services staff, we develop staff skills with a } \\
\text { view to INS' long-term future development }\end{array}$ & (1) never - (5) always \\
\hline 41 & $\begin{array}{l}\text { In Information Services, we scan and examine our environment } \\
\text { systematically to anticipate change }\end{array}$ & (1) never - (5) always \\
\hline 42 & $\begin{array}{l}\text { In Information Services, we react to approaching changes by } \\
\text { immediately updating our business strategy and processes }\end{array}$ & (1) never - (5) always \\
\hline 43 & $\begin{array}{l}\text { In Information Services, we jointly operate across different } \\
\text { functions and/or portfolios for strategic decision-making }\end{array}$ & (1) never - (5) always \\
\hline 44 & $\begin{array}{l}\text { In Information Services, we encourage early involvement of } \\
\text { several departments and/or functions in new product and/or } \\
\text { service development }\end{array}$ & (1) never - (5) always \\
\hline 45 & $\begin{array}{l}\text { In Information Services, we have a process to inform ourselves } \\
\text { about information technology innovations }\end{array}$ & (1) never - (5) always \\
\hline 46 & $\begin{array}{l}\text { In Information Services, we strategically invest in appropriate } \\
\text { technologies and have a clear vision how information technology } \\
\text { contributes to business value }\end{array}$ & (1) never - (5) always \\
\hline 47 & $\begin{array}{l}\text { In Information Services, we focus on our core competencies and } \\
\text { delegate further tasks to our partners }\end{array}$ & (1) never - (5) always \\
\hline
\end{tabular}




\begin{tabular}{|l|l|l|}
\hline 48 & $\begin{array}{l}\text { In Information Services, we select our partners and subcontractors } \\
\text { by quality criteria (rather than pure cost-based decisions) }\end{array}$ & (1) never - (5) always \\
\hline 49 & $\begin{array}{l}\text { In Information Services, we align all our activities to customer } \\
\text { requirements and needs }\end{array}$ & (1) never - (5) always \\
\hline 50 & $\begin{array}{l}\text { In Information Services, we closely collaborate with and } \\
\text { encourage feedback from our customers and partners }\end{array}$ & (1) never - (5) always \\
\hline 51 & $\begin{array}{l}\text { In Information Services, we design our processes to include early } \\
\text { feedback and adaptation }\end{array}$ & (1) never - (5) always \\
\hline 52 & $\begin{array}{l}\text { In Information Services, we are able to rapidly gain the approvals } \\
\text { needed }\end{array}$ & (1) never - (5) always \\
\hline
\end{tabular}

Organisational agility maturity model

Likert-Type Scale Response values (used as described in 3.4)

(1) not at all (2) a little (3) partly (4) mainly (5) completely

(1) none (2) few (3) some (4) many (5) all

(1) never (2) seldom (3) sometimes (4) often (5) always 


\section{Appendix 2. Survey questions-Staff question set}

The questions listed below were utilised in the survey instrument and presented for general staff (employees) to complete

\begin{tabular}{|c|c|c|}
\hline Order & Question Text & Scale \\
\hline 1 & $\begin{array}{l}\text { Information Services values a culture that considers team work as an } \\
\text { integral part }\end{array}$ & (1) not at all - (5) completely \\
\hline 2 & $\begin{array}{l}\text { Information Services values a culture that accepts and supports } \\
\text { decisions and proposals of staff }\end{array}$ & (1) not at all - (5) completely \\
\hline 3 & $\begin{array}{l}\text { Information Services values a culture that is supportive of } \\
\text { experimentation and the use of innovative ideas }\end{array}$ & (1) not at all - (5) completely \\
\hline 4 & $\begin{array}{l}\text { Information Services values a culture that considers changing customer- } \\
\text { related requirements as opportunities }\end{array}$ & (1) not at all - (5) completely \\
\hline 5 & $\begin{array}{l}\text { Information Services values a culture that nurtures an environment } \\
\text { where people trust and respect each other }\end{array}$ & (1) not at all - (5) completely \\
\hline 6 & $\begin{array}{l}\text { Information Services prefers proactive continuous improvement rather } \\
\text { than reacting to crisis or fire-fighting }\end{array}$ & (1) not at all - (5) completely \\
\hline 7 & $\begin{array}{l}\text { Information Services prefers flat hierarchies or simple structures to } \\
\text { eliminate barriers between individuals and/or teams }\end{array}$ & (1) not at all - (5) completely \\
\hline 8 & Information Services prefers a values-based leadership approach & (1) not at all - (5) completely \\
\hline 9 & Information Services prefers transparency of information for staff & (1) not at all - (5) completely \\
\hline 10 & $\begin{array}{l}\text { Information Services has a process for managing suggestions for } \\
\text { improvement, new ideas and solutions from all levels }\end{array}$ & (1) not at all - (5) completely \\
\hline 11 & Information Services has a structured staff training program & (1) not at all - (5) completely \\
\hline 12 & $\begin{array}{l}\text { Information Services has staff who have a good understanding of how } \\
\text { their own job relates to INS overall }\end{array}$ & (1) not at all - (5) completely \\
\hline 13 & $\begin{array}{l}\text { Information Services has a strategic direction that is clearly } \\
\text { communicated to all hierarchical levels in terms easily understood by all }\end{array}$ & (1) not at all - (5) completely \\
\hline 14 & $\begin{array}{l}\text { Information Services has a process to encourage our staff to upgrade } \\
\text { their skills and training }\end{array}$ & (1) not at all - (5) completely \\
\hline 15 & $\begin{array}{l}\text { Information Services has a strategic approach which fosters learning as } \\
\text { a crucial element }\end{array}$ & (1) not at all - (5) completely \\
\hline 16 & $\begin{array}{l}\text { Information Services has information systems and technologies that } \\
\text { make organisational information easily accessible to all staff }\end{array}$ & (1) not at all - (5) completely \\
\hline 17 & $\begin{array}{l}\text { Information Services has information systems and technologies that are } \\
\text { integrated among different departments and/or business units }\end{array}$ & (1) not at all - (5) completely \\
\hline 18 & $\begin{array}{l}\text { Information Services has information systems and technologies that are } \\
\text { standardised or comparable among different departments and/or } \\
\text { business units }\end{array}$ & (1) not at all - (5) completely \\
\hline 19 & $\begin{array}{l}\text { My manager maintains an informal management style with focus on } \\
\text { coaching and inspiring people }\end{array}$ & (1) not at all - (5) completely \\
\hline 20 & My manager has the knowledge and skills necessary to manage change & (1) not at all - (5) completely \\
\hline 21 & $\begin{array}{l}\text { My manager manages the sharing of information know-how and } \\
\text { knowledge among staff appropriately }\end{array}$ & (1) not at all - (5) completely \\
\hline 22 & $\begin{array}{l}\text { My manager encourages staff at lower levels to make decisions and } \\
\text { take responsibility }\end{array}$ & (1) not at all - (5) completely \\
\hline 23 & $\begin{array}{l}\text { My manager is empowered to make decisions needed to improve } \\
\text { services }\end{array}$ & (1) not at all - (5) completely \\
\hline 24 & My manager trusts staff to get their job done & (1) not at all - (5) completely \\
\hline 25 & $\begin{array}{l}\text { My manager fosters and enables staff to take responsibility and } \\
\text { contribute to change }\end{array}$ & (1) not at all - (5) completely \\
\hline 26 & My manager is aware of the broad range of skills within my team & (1) not at all - (5) completely \\
\hline 27 & $\begin{array}{l}\text { My manager acknowledges mistakes without delay and visibly adjusts } \\
\text { their actions }\end{array}$ & (1) not at all - (5) completely \\
\hline 28 & My manager acknowledges and tolerates ambiguity & (1) not at all - (5) completely \\
\hline
\end{tabular}




\begin{tabular}{|c|c|c|}
\hline 29 & $\begin{array}{l}\text { Staff in my portfolio are able to act with a view to continuous } \\
\text { improvement of our products, services, processes, and/or working } \\
\text { methods }\end{array}$ & (1) none - (5) all \\
\hline 30 & $\begin{array}{l}\text { Staff in my portfolio communicate with each other with trust, goodwill, } \\
\text { and esteem }\end{array}$ & (1) none - (5) all \\
\hline 31 & $\begin{array}{l}\text { Staff in my portfolio can re-organise continuously in different team } \\
\text { configurations to meet changing requirements and the newly arising } \\
\text { challenges }\end{array}$ & (1) none - (5) all \\
\hline 32 & $\begin{array}{l}\text { Staff in my portfolio collaborate closely with different teams and across } \\
\text { portfolios }\end{array}$ & (1) never - (5) always \\
\hline 33 & $\begin{array}{l}\text { Staff in my portfolio reflect at regular intervals on how to become more } \\
\text { effective in their team, then tune and adjust their behaviour } \\
\text { accordingly }\end{array}$ & (1) never - (5) always \\
\hline 34 & Staff in my portfolio work in small teams in their projects & (1) never - (5) always \\
\hline 35 & $\begin{array}{l}\text { Staff in my portfolio rotate among different activities, tasks, positions } \\
\text { or departments }\end{array}$ & (1) never - (5) always \\
\hline 36 & $\begin{array}{l}\text { Regarding Information Services we offer reward \& recognition not only } \\
\text { for individuals but for the team and their contribution to the overall } \\
\text { organisation }\end{array}$ & (1) never - (5) always \\
\hline 37 & $\begin{array}{l}\text { Regarding Information Services we raise staff strategic awareness e.g. } \\
\text { workshops and discussions }\end{array}$ & (1) never - (5) always \\
\hline 38 & $\begin{array}{l}\text { In Information Services we regularly scan and examine our environment } \\
\text { to anticipate change }\end{array}$ & (1) never - (5) always \\
\hline 39 & $\begin{array}{l}\text { In Information Services we have a process to inform ourselves about } \\
\text { information technology innovations }\end{array}$ & (1) never - (5) always \\
\hline 40 & $\begin{array}{l}\text { In Information Services we align all our activities to customer } \\
\text { requirements and needs }\end{array}$ & (1) never - (5) always \\
\hline
\end{tabular}

Organisational agility maturity model

Likert-Type Scale Response values (used as described in 3.4)

(1) not at all (2) a little (3) partly (4) mainly (5) completely

(1) none (2) few (3) some (4) many (5) all

(1) never (2) seldom (3) sometimes (4) often (5) always 


\section{Appendix 3. Survey questions-full question set grouped by themes and sub-themes (category)}

The themes correspond to the six dimensions of the Ace Agility Index; the sub-themes (categories) draw upon work done by Wendler (as explained in 3.4)

\begin{tabular}{|c|c|c|}
\hline Theme & Category & Question Text \\
\hline Culture & Accountability & $\begin{array}{l}\text { Information Services values a culture that ... embraces accountability from } \\
\text { top to bottom }\end{array}$ \\
\hline Culture & Accountability & $\begin{array}{l}\text { My manager ... fosters and enables staff to take responsibility and contribute } \\
\text { to change }\end{array}$ \\
\hline Culture & Accountability & My manager ... is empowered to make decisions needed to improve services \\
\hline Culture & Accountability & $\begin{array}{l}\text { My manager .... encourages staff at lower levels to make decisions and take } \\
\text { responsibility }\end{array}$ \\
\hline Culture & Accountability & My staff ... are prepared to take responsibility for their own decisions \\
\hline Culture & Accountability & $\begin{array}{l}\text { Regarding Information Services staff, we ... encourage staff at lower levels to } \\
\text { make decisions and take responsibility }\end{array}$ \\
\hline Culture & Trust & Information Services prefers ... transparency of information for staff \\
\hline Culture & Trust & $\begin{array}{l}\text { Information Services values a culture that ... nurtures an environment where } \\
\text { people trust and respect each other }\end{array}$ \\
\hline Culture & Trust & $\begin{array}{l}\text { Staff in my portfolio ... communicate with each other with trust, goodwill, } \\
\text { and esteem }\end{array}$ \\
\hline Culture & $\begin{array}{l}\text { Values and } \\
\text { Principles }\end{array}$ & $\begin{array}{l}\text { In Information Services, we ... strategically invest in appropriate technologies } \\
\text { and have a clear vision how IT contributes to business value }\end{array}$ \\
\hline Culture & $\begin{array}{l}\text { Values and } \\
\text { Principles }\end{array}$ & $\begin{array}{l}\text { Information Services has ... a strategic approach which fosters learning as a } \\
\text { crucial element }\end{array}$ \\
\hline Culture & $\begin{array}{l}\text { Values and } \\
\text { Principles }\end{array}$ & Information Services prefers ... a values-based leadership approach \\
\hline Culture & $\begin{array}{l}\text { Values and } \\
\text { Principles }\end{array}$ & $\begin{array}{l}\text { Information Services prefers ... implementation of guiding principles with } \\
\text { clear direction, so that all staff understand their contribution }\end{array}$ \\
\hline Culture & $\begin{array}{l}\text { Values and } \\
\text { Principles }\end{array}$ & $\begin{array}{l}\text { Information Services prefers ... simplicity, i. e. skipping product and/or } \\
\text { service features that go beyond the customer requirements }\end{array}$ \\
\hline Culture & $\begin{array}{l}\text { Values and } \\
\text { Principles }\end{array}$ & $\begin{array}{l}\text { Information Services values a culture that ... considers changing customer- } \\
\text { related requirements as opportunities }\end{array}$ \\
\hline Culture & $\begin{array}{l}\text { Values and } \\
\text { Principles }\end{array}$ & $\begin{array}{l}\text { Staff in my portfolio ... are able to act with a view to continuous } \\
\text { improvement of our products, services, processes, and/or working methods }\end{array}$ \\
\hline Innovation & Flexibility & In Information Services, we ... are able to rapidly gain the approvals needed \\
\hline Innovation & Flexibility & $\begin{array}{l}\text { Information Services has information systems and technologies that ... are } \\
\text { standardised or comparable among different departments and/or business } \\
\text { units }\end{array}$ \\
\hline Innovation & Flexibility & $\begin{array}{l}\text { Information Services managers within my portfolio ... flexibly deploy their } \\
\text { resources (material, financial, human ....) to make use of opportunities and } \\
\text { minimise threats }\end{array}$ \\
\hline Innovation & Flexibility & $\begin{array}{l}\text { Information Services managers within my portfolio ... quickly implement } \\
\text { changes in products and/or services }\end{array}$ \\
\hline Innovation & Proactivity & $\begin{array}{l}\text { Information Services has ... a process for managing suggestions for } \\
\text { improvement, new ideas, and solutions from all levels }\end{array}$ \\
\hline Innovation & Proactivity & $\begin{array}{l}\text { Information Services has information systems and technologies that ... } \\
\text { provide rapid feedback on operations and keep intelligence on changing } \\
\text { conditions }\end{array}$ \\
\hline Innovation & Proactivity & $\begin{array}{l}\text { Information Services managers within my portfolio ... recognise } \\
\text { opportunities for innovation in products, services and/or processes which will } \\
\text { deliver benefits for the University }\end{array}$ \\
\hline Innovation & Proactivity & $\begin{array}{l}\text { Information Services values a culture that .... is supportive of experimentation } \\
\text { and the use of innovative ideas }\end{array}$ \\
\hline $\begin{array}{l}\text { Leadership and } \\
\text { Management }\end{array}$ & Communication & $\begin{array}{l}\text { Information Services has } \ldots \text {. a process for managing suggestions for } \\
\text { improvement, new ideas, and solutions from all levels }\end{array}$ \\
\hline
\end{tabular}




\begin{tabular}{|c|c|c|}
\hline $\begin{array}{l}\text { Leadership and } \\
\text { Management }\end{array}$ & Communication & $\begin{array}{l}\text { Information Services has.... a strategic direction that is clearly communicated } \\
\text { to all hierarchical levels in terms easily understood by all }\end{array}$ \\
\hline $\begin{array}{l}\text { Leadership and } \\
\text { Management }\end{array}$ & Communication & $\begin{array}{l}\text { Information Services has information systems and technologies that . . . make } \\
\text { organisational information easily accessible to all staff }\end{array}$ \\
\hline $\begin{array}{l}\text { Leadership and } \\
\text { Management }\end{array}$ & Communication & $\begin{array}{l}\text { My manager ... manages the sharing of information, know-how, and } \\
\text { knowledge among staff appropriately }\end{array}$ \\
\hline $\begin{array}{l}\text { Leadership and } \\
\text { Management }\end{array}$ & Communication & My manager ... is aware of the broad range of skills within my team \\
\hline $\begin{array}{l}\text { Leadership and } \\
\text { Management }\end{array}$ & Communication & $\begin{array}{l}\text { Regarding Information Services, we ... raise staff's strategic awareness, e.g. } \\
\text { workshops and discussions }\end{array}$ \\
\hline $\begin{array}{l}\text { Leadership and } \\
\text { Management }\end{array}$ & Risk & $\begin{array}{l}\text { Information Services has information systems and technologies that ... } \\
\text { enable decentralisation in decision making }\end{array}$ \\
\hline $\begin{array}{l}\text { Leadership and } \\
\text { Management }\end{array}$ & Risk & $\begin{array}{l}\text { Information Services values a culture that . . . accepts and supports decisions } \\
\text { and proposals of staff }\end{array}$ \\
\hline $\begin{array}{l}\text { Leadership and } \\
\text { Management }\end{array}$ & Risk & My manager ... trusts staff to get their job done \\
\hline $\begin{array}{l}\text { Leadership and } \\
\text { Management }\end{array}$ & Risk & My staff . . . acknowledge mistakes quickly \\
\hline $\begin{array}{l}\text { Leadership and } \\
\text { Management }\end{array}$ & Risk & Regarding Information Services staff, we ... trust them to get their job done \\
\hline $\begin{array}{l}\text { Leadership and } \\
\text { Management }\end{array}$ & Style & $\begin{array}{l}\text { Information Services managers within my portfolio . . . acknowledge and } \\
\text { tolerate ambiguity }\end{array}$ \\
\hline $\begin{array}{l}\text { Leadership and } \\
\text { Management }\end{array}$ & Style & My manager ... . acknowledges and tolerates ambiguity \\
\hline $\begin{array}{l}\text { Leadership and } \\
\text { Management }\end{array}$ & Style & $\begin{array}{l}\text { My manager ... acknowledges mistakes without delay, and visibly adjust their } \\
\text { actions }\end{array}$ \\
\hline $\begin{array}{l}\text { Leadership and } \\
\text { Management }\end{array}$ & Style & $\begin{array}{l}\text { Regarding Information Services, we . . offer reward \& recognition not only } \\
\text { for individuals, but for the team and their contribution to the overall } \\
\text { organisation }\end{array}$ \\
\hline $\begin{array}{l}\text { Learning and } \\
\text { Change }\end{array}$ & $\begin{array}{l}\text { Organisational } \\
\text { Learning }\end{array}$ & $\begin{array}{l}\text { My staff ... . are willing to continuously learn from one another and to pass } \\
\text { their knowledge to others }\end{array}$ \\
\hline $\begin{array}{l}\text { Learning and } \\
\text { Change }\end{array}$ & $\begin{array}{l}\text { Organisational } \\
\text { Learning }\end{array}$ & $\begin{array}{l}\text { My staff.... are willing to learn and are prepared to constantly access, apply } \\
\text { and update knowledge }\end{array}$ \\
\hline $\begin{array}{l}\text { Learning and } \\
\text { Change }\end{array}$ & $\begin{array}{l}\text { Organisational } \\
\text { Learning }\end{array}$ & $\begin{array}{l}\text { My staff . . . sense, perceive, or anticipate the best opportunities which come } \\
\text { up in our environment }\end{array}$ \\
\hline $\begin{array}{l}\text { Learning and } \\
\text { Change }\end{array}$ & $\begin{array}{l}\text { Skills } \\
\text { Development }\end{array}$ & Information Services has . . . a structured staff training program \\
\hline $\begin{array}{l}\text { Learning and } \\
\text { Change }\end{array}$ & $\begin{array}{l}\text { Skills } \\
\text { Development }\end{array}$ & $\begin{array}{l}\text { Information Services managers within my portfolio ... . maintain an informal } \\
\text { management style with focus on coaching and inspiring people }\end{array}$ \\
\hline $\begin{array}{l}\text { Learning and } \\
\text { Change }\end{array}$ & $\begin{array}{l}\text { Skills } \\
\text { Development }\end{array}$ & $\begin{array}{l}\text { My manager ... maintains an informal management style with focus on } \\
\text { coaching and inspiring people }\end{array}$ \\
\hline $\begin{array}{l}\text { Learning and } \\
\text { Change }\end{array}$ & $\begin{array}{l}\text { Skills } \\
\text { Development }\end{array}$ & $\begin{array}{l}\text { My staff ... have a broad range of skills which can be applied to other tasks } \\
\text { when needed }\end{array}$ \\
\hline $\begin{array}{l}\text { Learning and } \\
\text { Change }\end{array}$ & $\begin{array}{l}\text { Workforce } \\
\text { Capability }\end{array}$ & $\begin{array}{l}\text { Information Services has ... staff who have a good understanding of how } \\
\text { their own job relates to INS' overall }\end{array}$ \\
\hline $\begin{array}{l}\text { Learning and } \\
\text { Change }\end{array}$ & $\begin{array}{l}\text { Workforce } \\
\text { Capability }\end{array}$ & $\begin{array}{l}\text { Information Services has information systems and technologies that .... } \\
\text { provide information helping our staff to quickly respond to change }\end{array}$ \\
\hline $\begin{array}{l}\text { Learning and } \\
\text { Change }\end{array}$ & $\begin{array}{l}\text { Workforce } \\
\text { Capability }\end{array}$ & My manager ... has the knowledge and skills necessary to manage change \\
\hline $\begin{array}{l}\text { Learning and } \\
\text { Change }\end{array}$ & $\begin{array}{l}\text { Workforce } \\
\text { Capability }\end{array}$ & My staff . . . are self-motivated \\
\hline Strategy & Engagement & $\begin{array}{l}\text { In Information Services, we ... closely collaborate with and encourage } \\
\text { feedback from our customers and partners }\end{array}$ \\
\hline Strategy & Engagement & $\begin{array}{l}\text { In Information Services, we ... design our processes to include early feedback } \\
\text { and adaptation }\end{array}$ \\
\hline
\end{tabular}




\begin{tabular}{|c|c|c|}
\hline Strategy & Engagement & $\begin{array}{l}\text { In Information Services, we ... f focus on our core competencies and delegate } \\
\text { further tasks to our partners }\end{array}$ \\
\hline Strategy & $\begin{array}{l}\text { Industry } \\
\text { Awareness }\end{array}$ & $\begin{array}{l}\text { In Information Services, we ... have a process to inform ourselves about } \\
\text { information technology innovations }\end{array}$ \\
\hline Strategy & $\begin{array}{l}\text { Industry } \\
\text { Awareness }\end{array}$ & $\begin{array}{l}\text { In Information Services, we ... regularly scan and examine our environment } \\
\text { to anticipate change }\end{array}$ \\
\hline Strategy & $\begin{array}{l}\text { Industry } \\
\text { Awareness }\end{array}$ & $\begin{array}{l}\text { In Information Services, we ... scan and examine our environment } \\
\text { systematically to anticipate change }\end{array}$ \\
\hline Strategy & $\begin{array}{l}\text { Industry } \\
\text { Awareness }\end{array}$ & $\begin{array}{l}\text { In Information Services, we ... select our partners and subcontractors by } \\
\text { quality criteria (rather than pure cost-based decisions) }\end{array}$ \\
\hline Strategy & Planning & $\begin{array}{l}\text { In Information Services, we ... . align all our activities to customer } \\
\text { requirements and needs }\end{array}$ \\
\hline Strategy & Planning & $\begin{array}{l}\text { In Information Services, we ... react to approaching changes by immediately } \\
\text { updating our business strategy and processes }\end{array}$ \\
\hline Strategy & Planning & $\begin{array}{l}\text { Information Services has ... a process to encourage our staff to upgrade their } \\
\text { skills and training }\end{array}$ \\
\hline Strategy & Planning & $\begin{array}{l}\text { Information Services prefers . . . a proactive continuous improvement rather } \\
\text { than reacting to crisis or "fire-fighting" }\end{array}$ \\
\hline Strategy & Planning & $\begin{array}{l}\text { Regarding Information Services staff, we ... develop staff skills with a view to } \\
\text { INS' long-term future development }\end{array}$ \\
\hline Strategy & Planning & $\begin{array}{l}\text { Regarding Information Services staff, we ... encourage our staff to upgrade } \\
\text { their skills and training }\end{array}$ \\
\hline Structure & Adaptability & $\begin{array}{l}\text { My staff . . . can re-organise continuously in different team configurations to } \\
\text { meet changing requirements and the newly arising challenges }\end{array}$ \\
\hline Structure & Adaptability & My staff . . . rotate among different activities, tasks, positions or departments \\
\hline Structure & Adaptability & $\begin{array}{l}\text { Regarding Information Services staff, we ... provide opportunities for staff to } \\
\text { multi-skill staff, e.g. job rotation, job mobility }\end{array}$ \\
\hline Structure & Adaptability & $\begin{array}{l}\text { Staff in my portfolio . . . can re-organise continuously in different team } \\
\text { configurations to meet changing requirements and the newly arising } \\
\text { challenges }\end{array}$ \\
\hline Structure & Adaptability & $\begin{array}{l}\text { Staff in my portfolio ... reflect at regular intervals on how to become more } \\
\text { effective in their team, then tune and adjust their behaviour accordingly }\end{array}$ \\
\hline Structure & Adaptability & $\begin{array}{l}\text { Staff in my portfolio ... rotate among different activities, tasks, positions or } \\
\text { departments }\end{array}$ \\
\hline Structure & Collaboration & $\begin{array}{l}\text { In Information Services, we ... encourage early involvement of several } \\
\text { departments and/or functions in new product and/or service development }\end{array}$ \\
\hline Structure & Collaboration & $\begin{array}{l}\text { Information Services has information systems and technologies that . . . are } \\
\text { integrated among different departments and / or business units }\end{array}$ \\
\hline Structure & Collaboration & $\begin{array}{l}\text { Information Services has information systems and technologies that. . . make } \\
\text { organisational information easily accessible to all staff }\end{array}$ \\
\hline Structure & Collaboration & $\begin{array}{l}\text { Information Services prefers ...... flat hierarchies or simple structures to } \\
\text { eliminate barriers between individuals and/or teams }\end{array}$ \\
\hline Structure & Collaboration & $\begin{array}{l}\text { Information Services values a culture that ... considers team work as an } \\
\text { integral part }\end{array}$ \\
\hline Structure & Cooperation & $\begin{array}{l}\text { In Information Services, we ... jointly operate across different functions } \\
\text { and/or portfolios for strategic decision making }\end{array}$ \\
\hline Structure & Cooperation & My staff . . . collaborate closely with different teams and across portfolios \\
\hline Structure & Cooperation & My staff . . . work in small teams in their projects \\
\hline Structure & Cooperation & $\begin{array}{l}\text { Staff in my portfolio ... collaborate closely with different teams and across } \\
\text { portfolios }\end{array}$ \\
\hline Structure & Cooperation & Staff in my portfolio . . . work in small teams in their projects \\
\hline
\end{tabular}

\section{About the authors}

David Gunsberg is Director of the Planning and Engagement within Digital Solutions, Griffith University. He is responsible for the delivery of the Division's portfolio of transformational projects. $\mathrm{He}$ is Passionate Advocate of placing the customer at the heart of corporate strategy, and is also known for his focus on performance and his track record of developing future leaders. Prior to joining 
Griffith University, David worked as Strategic Consultant for five years, focussing on the areas of corporate transformation, strategy development and high performance leadership.

Bruce Callow is Chief Digital Officer for Griffith University. Previous to this current role, Bruce was Director of Information and Communication Technology Services at the University. He has more than 15 years' experience in the higher education industry with 30 plus years in total in the IT industry, government, private and education areas.

Brett Ryan is Manager of the Policy, Planning and Performance within Digital Solutions, Griffith University. Brett is Planning Professional with seven years' experience in the higher education sector. He works strategically with executives to coordinate and draft strategic and operational plans, administers the collection performance metrics, runs staff surveys, and facilitates engagement and operational reporting. Previously, he worked in student surveys.

Jolyon Suthers is Senior Enterprise Architect within Digital Solutions, Griffith University. He has been developing and maintaining the University's Enterprise Architecture since 2010, and has been developing Information Technology Solution Architectures for over 10 years. He has worked extensively in application design, development, business process mapping and project management for 18 years.

Penny Anne Baker is Project Manager (Special Operations) within Digital Solutions, Griffith University. Her current responsibilities include the management of business, functional, development and technical aspects of a wide range of service-related projects including, but not limited to, business improvement, organizational change, innovation, and workforce planning and development. She has previously worked as Business Analyst /Change Manager and as Senior computer-Training Specialist.

Dr Joanna Richardson is Library Strategy Advisor at Griffith University. Previously she was responsible for scholarly content and discovery services, including repositories, research publications and resource discovery. Joanna has also worked as Information Technology Librarian in university libraries in both North America and Australia, and has been Lecturer in Library and Information Science. Recent publications have been centred on library support for research and research data management frameworks. Dr Joanna Richardson is the corresponding author and can be contacted at: j.richardson@griffith.edu.au

For instructions on how to order reprints of this article, please visit our website: 


\section{e emeraldinsight}

\section{Journal of Organizational Change Management}

Applying an organisational agility maturity model

David Gunsberg, Bruce Callow, Brett Ryan, Jolyon Suthers, Penny Anne Baker, Joanna Richardson,

\section{Article information:}

To cite this document:

David Gunsberg, Bruce Callow, Brett Ryan, Jolyon Suthers, Penny Anne Baker, Joanna Richardson, (2018) "Applying an organisational agility maturity model", Journal of Organizational Change

Management, https://doi.org/10.1108/JOCM-10-2017-0398

Permanent link to this document:

https://doi.org/10.1108/JOCM-10-2017-0398

Downloaded on: 30 J uly 2018, At: 11:27 (PT)

References: this document contains references to 45 other documents.

To copy this document: permissions@emeraldinsight.com

The fulltext of this document has been downloaded 75 times since 2018*

\section{Users who downloaded this article also downloaded:}

,Anticipation of organizational change", Journal of Organizational Change Management, Vol.

0 Iss 0 pp. - <a href="https://doi.org/10.1108/JOCM-03-2017-0085">https://doi.org/10.1108/

JOCM-03-2017-0085</a>

(2018),"Change leadership in the 21st century", Journal of Organizational Change Management, Vol. 31 Iss 4 pp. 867-876 <a href="https://doi.org/10.1108/JOCM-02-2017-0042">https://doi.org/10.1108/ JOCM-02-2017-0042</a>

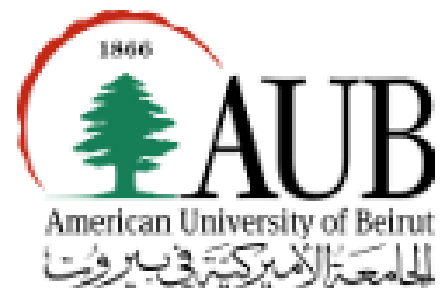

Access to this document was granted through an Emerald subscription provided by emeraldsrm: 365702 []

\section{For Authors}

If you would like to write for this, or any other Emerald publication, then please use our Emerald for Authors service information about how to choose which publication to write for and submission guidelines are available for all. Please visit www.emeraldinsight.com/ authors for more information.

\section{About Emerald www.emeraldinsight.com}

Emerald is a global publisher linking research and practice to the benefit of society. The company manages a portfolio of more than 290 journals and over 2,350 books and book series volumes, as well as providing an extensive range of online products and additional customer resources and services.

Emerald is both COUNTER 4 and TRANSFER compliant. The organization is a partner of the Committee on Publication Ethics (COPE) and also works with Portico and the LOCKSS initiative for digital archive preservation. 